SCJR 11, no. 1 (2016): 1-11

\title{
Synagoga and Ecclesia In Our Time: A Transformative Sculptural Statement in Traditional Form
}

\author{
JUDITH BOOKBINDER \\ judith.bookbinder@bc.edu \\ Boston College, Chestnut Hill, MA 02467
}

On September 25, 2015, a new bronze sculpture near the chapel of Saint Joseph's University in Philadelphia was dedicated to mark the fiftieth anniversary of the Second Vatican Council's 1965 declaration, Nostra Aetate, its "Declaration on the Relation of the Church to Non-Christian Religions." "Two days later, Pope Francis blessed the statue of two similar female figures seated side by side, one holding a Torah scroll, the other holding a Bible (figures 1 and 7). The title of the work, Synagoga and Ecclesia In Our Time, points backwards and forwards chronologically: "Synagoga and Ecclesia" refers to the long-standing Christian tradition, born in thirteenth-century Europe, of depicting the Church as a confident and victorious female figure in contrast to the defeated and broken female figure of Synagogue; "In Our Time" translates the declaration's opening Latin words, "nostra aetate." This declaration's fourth paragraph redirected Catholic discourse on Judaism. The sculpture also attempts to embody ideas that have emerged in the half-century since the council and that, in December 2015, found their most recent official articulation in the Pontifical Council for Religious Relations with the Jews' publication of "The Gifts and the Calling of God are Irrevocable" (Rom. 11:29): A Reflection on Theological Questions Pertaining to Catholic-Jewish Relations on the Occasion of the 50 th Anniversary of "Nostra Aetate" (No.4). ${ }^{3}$

\footnotetext{
${ }^{1}$ http://www.vatican.va/archive/hist_councils/ii_vatican_council/documents/vatii_decl_19651028_nostra-aetate_en.html.

${ }^{2}$ See Wolfgang S. Seiferth, Synagogue and Church in the Middle Ages (New York: Frederick Ungar, 1970); first published in German as Synagoge und Kirche im Mittelalter (München: Kösel, 1964).

${ }^{3}$ http://www.vatican.va/roman_curia/pontifical_councils/chrstuni/relations-jewsdocs/rc_pc_chrstuni_doc_20151210_ebraismo-nostra-aetate_en.html.

This verse from Romans has particular importance in the contemporary thinking about ChristianJewish relations. In 2014, Pope Francis stated: "I hold the Jewish people in special regard because their covenant with God has never been revoked, for 'the gifts and the call of God are irrevocable' (Rom 11:29)." Pope Francis, Evangelii Gaudium (2014), 247 (http://w2.vatican.va/content/francesco/en/apost_exhortations/documents/papafrancesco esortazione-ap 20131124 evangelii-gaudium.html). He is making explicit Nostra Aetate 4's paraphrase of Romans.
} 


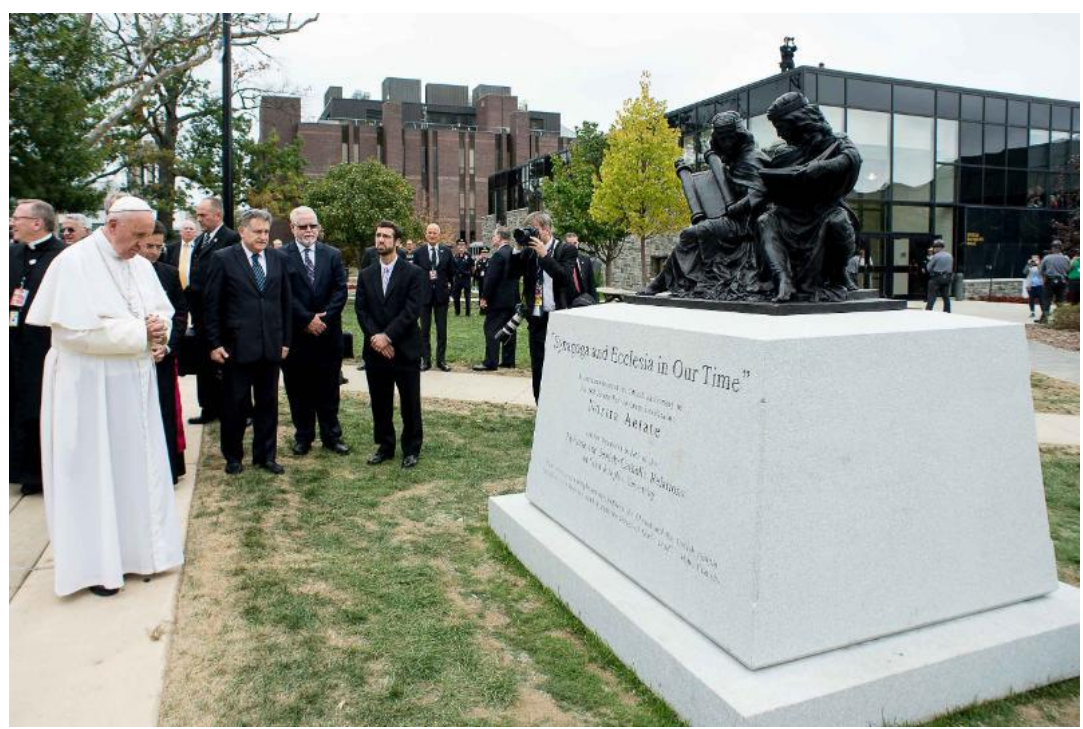

Figure 1. Pope Francis prays before Synagoga and Ecclesia in Our Time (2015) Saint Joseph's University, Philadelphia, September 27, 2015. Bronze sculpture by Joshua Koffman. Commissioned by Saint Joseph's University to mark the $50^{\text {th }}$ anniversary of Nostra Aetate (photograph by and courtesy of Melissa Kelly / melissakelly.com).

The form of the sculpture raises the question: in the twenty-first century and in the context of the transformation of the visual language of art in the last hundred years, how is the message of these modern documents embodied in two representational and generalized female figures wearing crowns and flowing robes in the academic art tradition of earlier centuries? The answer lies in the form and message of the sculpture and of the dialogic process that inspired it. Just as Nostra Aetate and "The Gifts and the Calling of God Are Irrevocable" anchor the theological bases of their new pronouncements about Judaism in the ancient words of the Christian Scriptures, so Joshua Koffman, the sculptor of Synagoga and Ecclesia In Our Time, imbeds his reconfiguration of this ancient visual trope in the form-language of works that have adorned churches for centuries. This essay will consider the effectiveness of the sculpture in terms of the message it was meant to convey and its validity as a creative statement in the early twenty-first century.

Koffman's work begins with the traditional configurations of "Church" and "Synagogue," which had been devised in medieval Europe to concretize the idea of supersession. As the Commission for Religious Relations with the Jews explains in the historical overview that opens its December statement,

On the part of many of the Church Fathers the so-called replacement theory or supersessionism steadily gained favor until in the Middle Ages it represented the standard theological foundation of the relationship with Judaism: the promises and commitments of God would no longer apply to Israel be- 
cause it had not recognized Jesus as the Messiah and the Son of God, but had been transferred to the Church of Jesus Christ which was now the true "new Israel", the new chosen people of God. ${ }^{4}$

Thus, stone figures in early thirteenth-century Gothic cathedrals throughout Europe, at Reims, Paris, Strasbourg, Freiburg, Bamberg, Magdeburg, and elsewhere embodied the notion that the triumphant Church replaced an obsolete Synagogue blind to the new relationship between the religious community and God. ${ }^{5}$ The Strasbourg Ecclesia (1230), for example, projects forward and stands elegantly and confidently, a crown on her head, her right hand firmly grasping a staff topped with a cross while a Bible is tucked securely under her left arm, and her left hand holds a chalice evoking the wine of the Eucharist (figure 2). In contrast, the accompanying blindfolded Synagoga twists uncomfortably; her right hand barely holds a broken staff, while one of the tablets of the Ten Commandments slips from her left hand. Her bare head reveals long hair, and the curves of her sensuous body contrast with Ecclesia's more modest form. ${ }^{6}$ In the thirteenth century, "there was a veritable explosion in the diversity and ferocity of antiJewish texts and artworks," Sara Lipton observes. "In a symbolic window in Chartres cathedral," she notes, "the personification of Synagoga has a snake wrapped around her eyes instead of the traditional blindfold.", Mary Boys describes the typical medieval Ecclesia, "standing erect and triumphant, symbol of the church of the victorious Christ, [while] Synagoga, in contrast, is a conquered figure, symbolic of Judaism's defeat and obsolescence." The message these figures were meant to convey, Boys eloquently states, was that, "God had only one blessing to give - and now Ecclesia, not Synagoga, received it.",

\footnotetext{
4 "The Gifts and the Calling of God are Irrevocable..." section 2, paragraph 17.

${ }^{5}$ See Nina Rove, The Jew, the Cathedral and the Medieval City: Synagoga and Ecclesia in the Thirteenth Century (Cambridge, UK: Cambridge University Press, 2011).

${ }^{6}$ On this motif, see: Elizabeth Monroe, "'Fair and Friendly, Sweet and Beautiful': Hopes for Jewish Conversion in Synagoga's Song of Songs Imagery," in Beyond the Yellow Badge: Anti-Judaism and Antisemitism in Medieval and Early Modern Visual Culture, ed. Mitchell B. Merback (Leiden, Boston: Brill, 2008), 33-61; Conrad Rudolph, Artistic Change at St-Denis: Abbot Suger's Program and the Early Twelfth-Century Controversy over Art (Princeton: Princeton University Press, 1999); Bernd Nicolai, "Orders in Stone: Social Reality and Artistic Approach. The Case of the Strasbourg South Portal," Gesta 41 (2002): 111-28; and Nina Rowe, "Rethinking Ecclesia and Synagoga in the Thirteenth Century," in Gothic Art \& Thought in the Later Medieval Period: Essays in Honor of Willibald Sauerländer, ed. Colum Hourihane (Princeton: Index of Christian Art, Princeton University; Philadelphia: University of Pennsylvania Press, 2011),265-91.

${ }^{7}$ Sara Lipton, "Christianity and Its Others: Jews, Muslims, and Pagans" in The Oxford Handbook of Medieval Christianity, ed. John H. Arnold (Oxford: Oxford University Press, 2014), 418. See also Sara Lipton, Dark Mirror: the Medieval Origins of anti-Jewish Iconography (New York: Metropoli$\tan$ Books/Henry Holt and Co., 2014).

${ }^{8}$ Mary C. Boys, Has God Only One Blessing?: Judaism as a Source of Christian Self-Understanding (NY and Mahwah, NJ: Paulist Press, 2000), 5.
} 


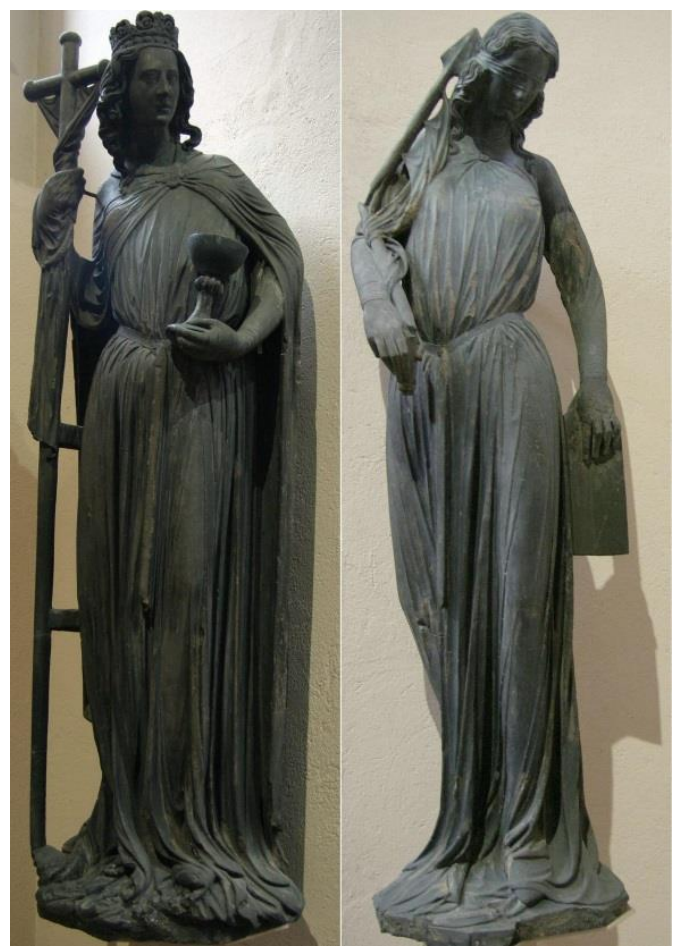

Figure 2. Ecclesia and Synagoga. Original sculptures from the façade of Strasbourg Cathedral, now in the Musée de l'Oeuvre Notre-Dame in Strasbourg (replaced by replicas on the façade) Photograph by Rama, Wikimedia Commons, Cc-by-sa-2.0-fr

Perhaps the most notorious recent American representations of Church and Synagogue pre-dating Koffman's reformulation of this theme remain today on the walls of Sargent Gallery at the third-floor entry to the Special Collections of the Boston Public Library in Copley Square. They are part of a cycle of paintings called Triumph of Religion, on which John Singer Sargent labored from 1895 to 1916 , in the hope of producing his greatest masterpiece. He borrowed from diverse visual sources to create this extremely complex program of images in the eclectic Beaux-Arts style. "For Sargent, authority rested in cultural precedents, art historical and literary," according to art historian Sally Promey. "He approached Triumph of Religion 'from the point of view of iconography'; his idea rested on a modern interpretation communicated by means of reworking the religious iconography of the past." 9 In response to criticism of his rendering of Church and Synagogue, Sargent wrote a letter to the editor of the Jewish Advocate in which he cited the iconography's medieval sources specifically at Reims and Strasbourg stating, "the traditional antecedents for Synagogue and Church establish an au-

\footnotetext{
${ }^{9}$ Sally M. Promey, Painting Religion in Public: John Singer Sargent's Triumph of Religion at the Boston Public Library (Princeton, NJ: Princeton University Press, 1999), 200.
} 
thoritative precedent."10 "In Triumph of Religion," Promey explains, "the Hebrew prophets signaled the emergence of religious subjectivity as Sermon on the Mount would signal its distilled expression." But the climactic image was never painted, and the blank panel where Sermon on the Mount was to have been installed highlights how problematic Sargent's concept was from the start because it reveals the degree to which the supersessionist notion had been naturalized in Sargent's mind. "The artist did not see," Promey concludes, "that his murals perpetuated, perhaps even exacerbated, old biases." 11

Framing the space where Sermon on the Mount was to complete the story of Triumph of Religion are panels with figures representing Church and Synagogue. Church (figure 3) is a powerful Virgin Mary seated on a throne, staring calmly and directly at the viewer, her enormous form dwarfing the lifeless body of Jesus collapsed between her legs while she holds a glowing chalice and wafer of the Eucharist and symbols of the Evangelists encircle her head. The figure is primarily modeled in grisaille tones that create the illusion of a form at once alive and carved in stone.

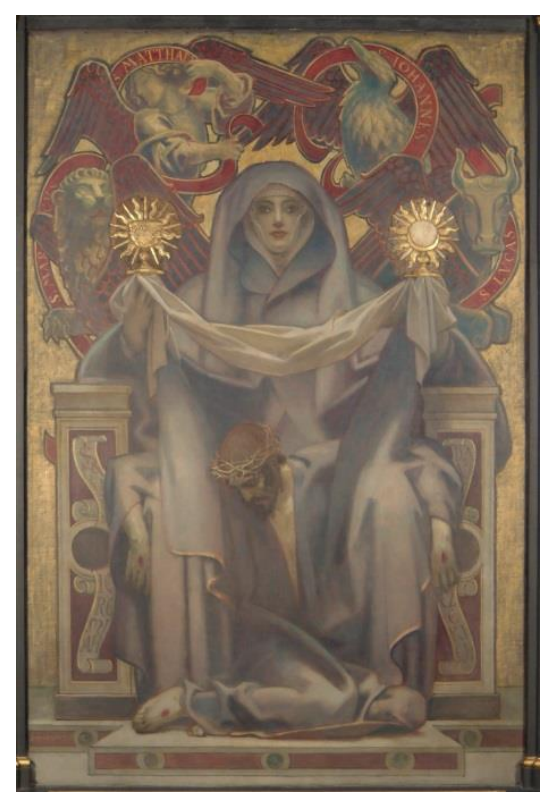

Figure 3. Church (1919) by John Singer Sargent. Oil on canvas, 243 x $161 \mathrm{~cm}$. On the east wall of Sargent Hall in the Boston Public Library. Courtesy of the Boston Public Library, taken by the Strauss Center for Conservation and Technical Studies during the 2003 restoration project of Sargent Hall.

\footnotetext{
${ }^{10}$ John Singer Sargent, letter to the editor (21 October 1919) printed in "Real Interpretation of "The Synagogue' Missing in John Singer Sargent's Explanation," Jewish Advocate, 23 October 1919, 1.

${ }^{11}$ Promey, 201.
} 
Opposite this imposing image is the panel of Synagogue (figure 4). Here another female figure, but pale and gaunt, collapses into a mass of draperies, the veils of the temple, which are falling around her. She struggles hopelessly to hold a broken staff with her left hand while also clutching a Torah scroll against her chest. A crown, askew at the side of her head, and her blindfold complete a figure that straddles the line between tragedy and farce. Promey argues that Sargent modeled Synagogue on Michelangelo's Cumaean Sibyl, ${ }^{12}$ but, aside from the contrapposto twist of the pose and a few superficial resemblances, there is little in this image of total defeat that bears comparison to the powerful, vigorous figure on the Sistine ceiling. For all of Sargent's efforts to insert his Church and Synagogue into an art historical context and for all of Promey's efforts to rationalize his concept, these images remain steeped in an antisemitic, supersessionist mindset. The outcry at the time of their installation in the library in 1919 shocked Sargent and frustrated his hopes for an artistic triumph. ${ }^{13}$

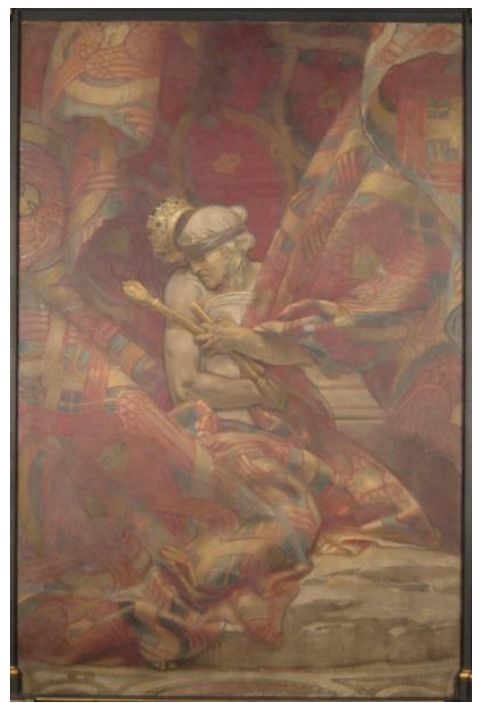

Figure 4. Synagogue (1919) by John Singer Sargent. Oil on canvas, 243 x $161 \mathrm{~cm}$. On the east wall of Sargent Hall in the Boston Public Library. Courtesy of the Boston Public Library, taken by the Strauss Center for Conservation and Technical Studies during the 2003 restoration project of Sargent Hall.

\footnotetext{
${ }^{12}$ Promey, 117.

${ }^{13}$ The controversy began in October 1919 when art critic, Frederick Wiiliam Coburn, stated: "If one were an orthodox Jew, a rabbi, or a cantor, it might be a little distasteful to have this middle-age fashion of depreciating his religion revived in a building supported by public taxation." Coburn, "In the World of Art," Boston Herald (October 10, 1919), C8. The debate continued through 1920 with resolutions and official requests to the Massachusetts legislature, the governor, and the trustees of the library from New York, Cleveland, Cincinnati, Detroit, Chicago, Pittsburgh, Baltimore, Louisville, and Nashville to remove Synagogue. In June 1922, the Massachusetts House and Senate passed a bill calling for the removal of Synagogue; but in April 1924, they repealed it.. See Promey, 176-186.
} 
More related to Michelangelo's figure style, Koffman's Synagoga and Ecclesia In Our Time (figure 7) attempts to channel the monumentality and dynamism of the Renaissance master's Sistine sibyls and prophets. ${ }^{14}$ Inspired by the Libyan Sibyl (figure 5) and the Prophet Isaiah (figure 6), for example, Koffman modeled his three-dimensional figures so that they turn in space. Their similar but slightly distinct facial features - more angular for Synagoga, more rounded for Ecclesiareveal emotion only in the slight upturn of their lips. The intensity of their relationship is visualized, instead, in the zig-zagging folds of their robes that seem to vibrate between them almost becoming a continuous play of highlights and shadows at the base, but ultimately maintaining their separate identities. The viewer's eye moves upward diagonally from the pointed toes of each figure, slightly more quickly, perhaps, along the more assertive line of Synagoga's left leg than the somewhat more relaxed line of Ecclesia's right leg, toward the center of the composition where the diagonals jump from one figure to the other and continue upward to culminate in the paired thoughtful heads and the large Torah scroll and Bible, which again point diagonally outward.

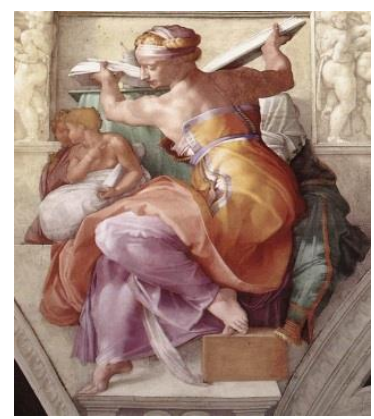

Figure 5. Libyan Sibyl (1508-1513) by Michelangelo. Fresco. Sistine chapel, Vatican, Rome.

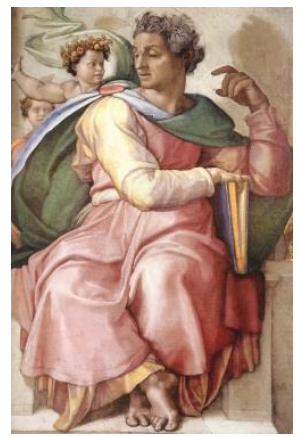

Figure 6. Prophet Isaiah (1508-1513) by Michelangelo. Fresco. Sistine chapel, Vatican, Rome.

\footnotetext{
${ }^{14}$ According to the Saint Joseph's University website, "Joshua Koffman was captivated by Greek and Renaissance art at an early age." He earned a BA in Fine Art at the University of California, Santa Cruz, and continued his studies at the Pennsylvania Academy of Fine Arts where he currently teaches.
} 


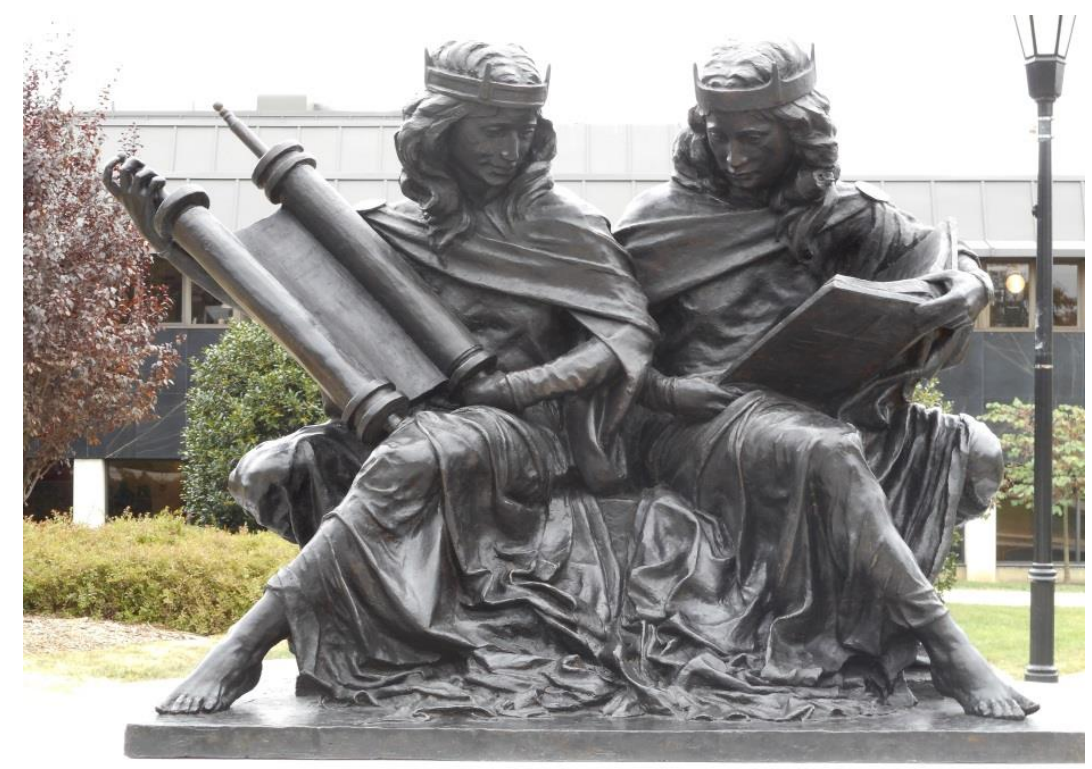

Figure 7. Synagoga and Ecclesia in Our Time (2015) Bronze sculpture by Joshua Koffman. Commissioned by Saint Joseph's University to mark the $50^{\text {th }}$ anniversary of Nostra Aetate (photograph by and courtesy of Melissa Kelly / melissakelly.com).

The x-shape of the composition, linked at the shoulders, is at once stable and dynamic. The figures support and reinforce one another as they lean inward to compare their separate texts. Synagoga's left shoulder overlaps Ecclesia's right arm, but that arm, in turn, seems to support Synagoga. At the same time, their extended legs suggest that this moment of stasis will end with each figure going in her own direction. As the Commission for Religious Relations with the Jews states, "The soil that nurtured both Jews and Christians is the Judaism of Jesus' time... Thus Jews and Christians have the same mother and can be seen, as it were, as two siblings who-as is the normal course of events for siblings-have developed in different directions." Gifts and the Calling of God are Irrevocable" today anchor their transformative declarations in the ancient words of the Bible, Koffman anchors his transformed Synagoga and Ecclesia in a nineteenth-century beaux-art adaptation of classical Renaissance style, an approach that appears to resonate with Pope Francis and, likely, with many other observers within and beyond the Catholic community, as the photograph taken on September 27, 2015 (figure 1) tends to evidence. ${ }^{16}$

\footnotetext{
${ }^{15}$ Section 2, paragraph 15.

${ }^{16}$ The beaux-art style of sculpture is represented in the works of such nineteenth-century American artists as Augustus Saint-Gaudens (1848-1907), Daniel Chester French (1850-1931), and Frederick William MacMonnies (1863-1937), although the seated figures of Art and Science (1920-1929) by Bela Lyon Pratt that frame the entrance steps to the Boston Public Library seem to relate most closely to Koffman's sculpture.
} 
The concept of the sculpture evolved under the guidance of Dr. Philip Cunningham and Dr. Adam Gregerman, co-directors of Saint Joseph University's Institute for Jewish-Catholic Relations. Cunningham explains: "Adam Gregerman and I...decided that SJU should mark the fiftieth anniversary of Nostra Aetate and the establishment of the Institute [for Jewish-Catholic Relations] in 1967...The SJU president, other university leaders, and the Institute's Board of Directors all thought that it was a great idea." After considering various motifs for capturing the spirit of these developments, Cunningham and Gregerman recalled Mary Boys' thought-provoking exploration of the Christian-Jewish relationship and its embodiment in "Synagoga and Ecclesia" imagery. "If God has more than one blessing, then we need to fashion new images of Synagoga and Ecclesia," she reasoned. "Each exists in her own integrity and vitality... They are partners in witnessing to and working for the reign of God."18 "Knowing of Mary Boys" work, we turned to Synagoga and Ecclesia as a concept, and everyone we consulted on and off campus found the concept exciting," Cunningham states. "Mary had the idea of reimagining Synagoga and Ecclesia for a post-Nostra Aetate Church." Cunningham and Gregerman invited local artists to submit sketches; they explained the history of the theme and how it would be reconfigured. "We wanted both figures to be crowned and dignified," Cunningham explains, "proud of their respective traditions." 19

Joshua Koffman's proposal captured Cunningham's and Gregerman's attention. "It was my initial designs (clay sketch models) that sparked the idea to represent the two as seated equals, sharing texts," Koffman explains. ${ }^{20} \mathrm{He}$ submitted photographs of six-inch high clay figures "that were dynamic and alive," Cunningham describes. "One of them...showed Synagoga and Ecclesia reclining together in flowing draperies. What was appealing about this sketch, and what images of the two figures simply standing alongside each other lacked, was their evident comfort with each other. There was a suggestion of interactivity that we immediately latched onto." Cunningham and Gregerman asked Koffman if he could develop the idea of the figures studying their respective sacred texts together. Cunningham explains, "This idea of joint study came from both traditional Jewish chavruta study of the Talmud in pairs and also from the experiences of the previous decades of Catholic-Jewish dialogue and two papal statements, one from Benedict XVI and the other from Francis (which we used on the sculpture base). Joshua took it from there. ${ }^{, 21}$ Koffman refined the poses of the figures to highlight their formal relationship, and he enlarged and defined the shapes of the Torah scroll and Bible so that their rectangular forms counter-balance each other. Yet, while Koffman achieves classical stasis and linear dynamism, the figures do not look at one another or at their texts. Rather, each seems to gaze inward, not quite

\footnotetext{
${ }^{17}$ Boys, 245-266.

${ }^{18}$ Boys, 6.

${ }^{19}$ Philip Cunningham, e-mail correspondence with author, May 25, 2016.

${ }^{20}$ Joshua Koffman, e-mail correspondence with author, May 24, 2016.

${ }^{21}$ Cunningham, e-mail correspondence.
} 
ready, perhaps, to engage in chavruta study or true dialogue. The sculpture, therefore, while taking major strides toward expressing the equality of Synagogue and Church, does not fully realize its goal of dialogue.

And what of the notion that a work of art ought to embody the formlanguage of its time? Koffman's sculpture clearly rejects contemporary approaches in favor of a beaux-art, classically inspired, late nineteenth-century style. Another recent rendering of the Synagoga and Ecclesia theme presents an alternative approach to Koffman's sculpture. It developed out of Boys' recognition that "the image of Jews and Christians as partners in witness and work is a new vision" that requires a new formulation. In 2000, she commissioned Paula Mary Turnbull, an artist member of her religious community, to create a pair of small brass sculptures that might serve as a prototype of such imagery. Turnbull constructs her Synagoga and Ecclesia (figure 8) of curved planes and arcing lines that move toward and away from each other in a dance-like interplay, with the specific message depending on the positioning of the two sculptures. The irregular planes and curvilinear ropes of drapery folds sparkle as light plays across their surfaces. Anatomy is abstracted in the service of movement and relationship. Turnbull acknowledges the visual vocabulary of abstraction that developed in the twentieth century and uses it to convey a spiritual message. It is a modest start toward the possibility of expressing the new vision of Synagogue and Church in a modern form-language.

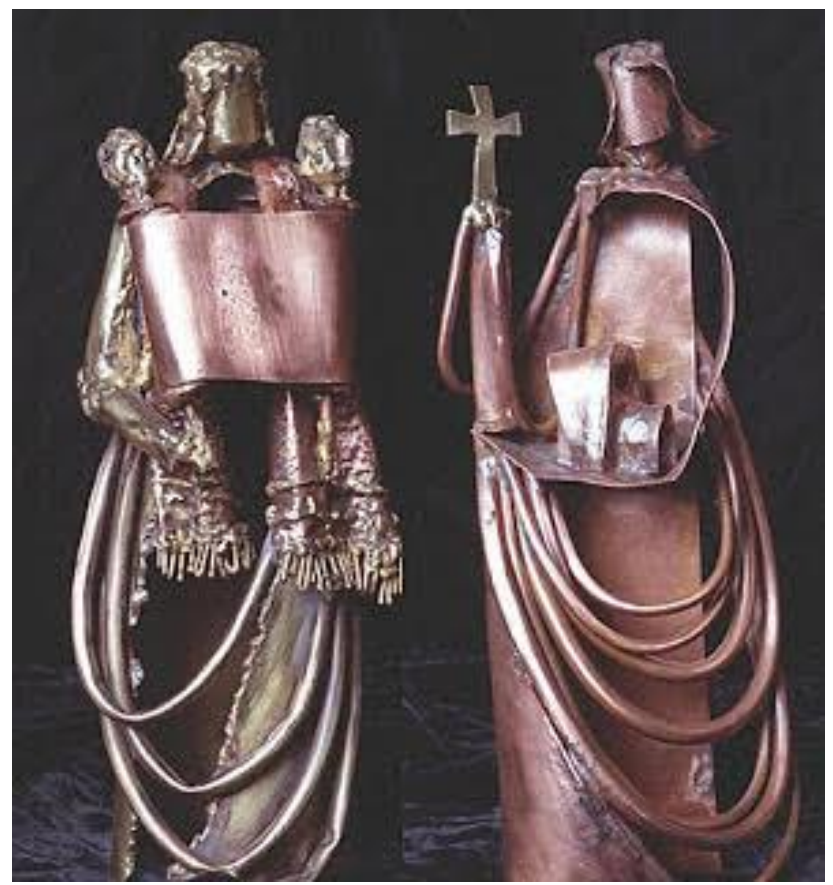

Figure 8. Ecclesia and Synagoga (2000) Brass sculpture by Paula Mary Turnbull, S.N.J.M. Photograph by Lynn Saville. 
To compare Koffman's sculpture to the sculpture of Michelangelo or Rodin, Alberto Giacometti or Henry Moore, much less Louise Bourgeois or Kiki Smith, for example, would be a pointless exercise. Koffman's sculpture has neither the power of works by the first two sculptors, nor does it aim for the originality and transgressiveness of the later four artists. Rather, it is the product of a conscious effort to visualize the new configuration of the Synagogue / Church relationship as a transformed outgrowth of traditions embedded in ancient religious teachings. How or even whether the theme of a newly understood Synagoga and Ecclesia will capture the imaginations of future artists remains to be seen. For now, Joshua Koffman's Synagoga and Ecclesia In Our Time is a tentative beginning in a form-language of the past. It embodies the new Catholic understanding of the relationship between Jews and Christians in a traditional, academic visual language that conveys this transformed idea to those who wish to hear and see it. It will be for other artists to consider whether or not a transformed theological construct can be captured in more contemporary, even radical, visual form. 